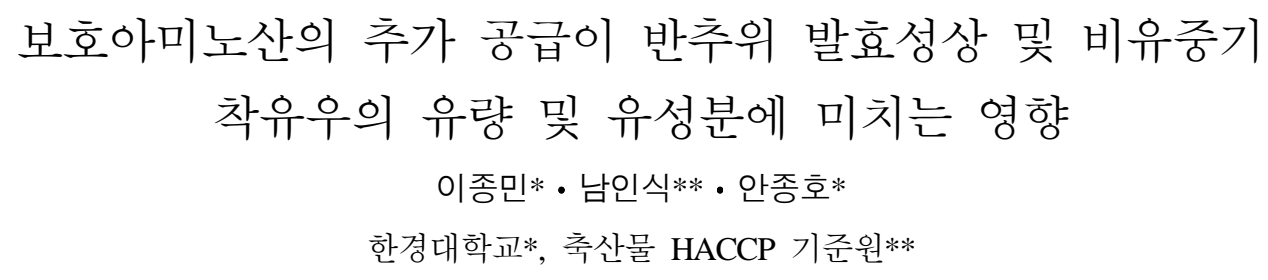

\title{
Effects of Supplementation of Ruminally Protected Amino Acids on In vitro Ruminal Parameters and Milk Yield and Milk Composition of Dairy Cows in Mid-lactation
} Jong Min Lee*, In Sik Nam** and Jong Ho Ahn*

Hankyong National University*, Korea Livestock Products HACCP Management Institute**

\begin{abstract}
This study was undertaken to investigate the effects of ruminally protected amino acids (Methionine and Lysine) on in vitro ruminal parameters, and in vivo milk yield and milk composition in mid-lactating cows. In the first in vitro experiment, there were no statistical significances between treatments in ruminal $\mathrm{pH}$ and dry matter digestibility during various incubation times. In the second in vivo experiment, milk yield decreased by $11.92 \%$ in control and $5.68 \%$ in the treatment respectively, but decrease rate of milk yield in the treatment was lower than control. Milk yields naturally decreased as time goes by since the DIMs (Days in milk) of the cows in experiment were in mid-lactation period. 4\% FCM (Fat corrected milk) and milk protein yields also, respectively, decreased by $11.25 \%$ and $11.09 \%$ in control and $6.16 \%$ and $5.47 \%$ in the treatment as compared with the intial. Milk protein and milk fat production were higher in the treatment $(0.90 \mathrm{~kg}, 1.10 \mathrm{~kg})$ than those of control $(0.66 \mathrm{~kg}, 0.79 \mathrm{~kg})$. Milk fat content significantly increased with supplementing protected amino acids as compared to control $(\mathrm{P}<0.05)$. From the above results, protected amino acids were positively utilized in the performances of mid-lactating cows without inhibiting rumen fermentation. Further investigation is suggested for essential amino acid composition and intestinal digestion rate out of rumen bypass protein in dietary protein to be estimated.
\end{abstract}

(Key words : Protected amino acid, Ruminal parameters, Milk yield, Milk compositions, Mid-lactating cows)

$$
\text { I. 서 론 }
$$

젖소의 사료 단백질 요구량에 있어서 일반적 으로 우유나 근육 단백질 생산을 위한 사료 단 백질 요구량에 대해 유량 $25 \mathrm{~kg}$ 을 생산하는 젖 소의 경우 반추위내에서 생성되는 미생물 단백 질만으로도 충분하다고 NRC (2001)에서 보고하
고 있다. 그러나 최근 착유우의 유전 육종 및 영양 분야의 발달과 사양관리 기술의 개선으로 고능력우가 증가하게 되어 이들의 성장 및 생 산 활동을 정상적으로 유지하기 위하여 필요한 단백질의 요구량이 증가되었고 새로운 단백질 개념이 도입되었다. 특히 고능력우나 비유초기 의 젖소에 있어서 NRC(2001)에서는 비유초기

Corresponding author : Jong Ho Ahn, Hankyong National University, Ansong, Gyonggi, 456-749, Korea Tel : 031-670-5124, Fax : 031-670-5127, E-mail : jhahn@hknu.ac.kr 
젖소에서 반추위비분해단백질이 전체 단백질 요구량의 $40 \%$ 이상 되어야 한다고 보고하고 있다.

또한 단백질의 이용성과 관련하여 소장에서 이용되는 bypass 단백질의 아미노산 조성과 관 련된 연구결과가 발표되고 있으며, 이의 아미 노산 조성과 변화를 통하여 단백질의 이용성을 증가시킬 수 있다는 연구보고가 발표되었다 (Chalupa 등, 1974). 젖소의 단백질 생산은 소장 으로부터 흡수되는 아미노산의 량에 따라 제한 되기도 하며 소장으로 흡수되는 아미노산의 량 은 반추위에서 bypass된 단백질량에 의해 영향 을 받는다. Hogan (1975)과 Schwab 등 (1976)은 methionine의 제 4위내 주입은 산유량, 유단백 질 및 유지방 생산량에 영향을 주지 않으나 lysine의 주입은 유단백질 함량을 $16 \%$ 증가시 켜 10 종류의 아미노산 혼합물을 급여한 것과 비슷한 효과를 나타내고 lysine과 methionine을 같이 주입할 때는 유단백질 함량이 $43 \%$ 증가 된다고 하였다. 이러한 연구 결과들이 보고되 면서 아미노산이 반추위내에서 분해되는 것을 방지하고 소장내에서 흡수 이용률을 증가시키 기 위하여 많은 학자들에 의해 연구되어 왔다 (Folman 등, 1981; Oldham, 1981; Roger 등, 1989; Canale 등, 1990).

그러나 이러한 연구들은 비유초기 젖소만을 대상으로 하였기 때문에 보호 아미노산 급여가 비유 중기 젖소에 미치는 영향에 관해서는 보 고된 것이 없다. 따라서 전 비유기간동안의 보 호아미노산 급여효과가 분명치 않은 문제점이 있으며, 이에 본 연구에서는 비유중기 젖소를 대상으로 하여 보호 lysine과 보호 methionine의 급여가 반추위 발효 성상 및 유량 및 유성분에 미치는 영향을 조사하였다.

\section{ㅁ. 재료 및 방법}

\section{1. 실험사료의 준비 및 반추위 발효성상 조사}

실험에 사용한 사료 원료와 배합량, 그리고 화학적 조성은 Table 1에 나타내었다. 본 실험 은 사료 내 보호아미노산을 사료에 첨가하여
반추위 내 위액성상의 변화 및 비유중기 착유 우의 산유성적을 평가하기 위하여 실시하였다. 사용한 보호아미노산은 한경대학교 반추동물영 양학실험실에서 gelatin과 oligosaccharide를 multicoating 기술을 이용하여 직접 제조하였으며 실 험 1 의 반추위 발효성상 조사를 위하여 보호라 이신 (PRLys, 2.71\%)과 보호메치오닌 (PRMet, 0.90 $\%$ )의 함량을 3:1 비율로 섞어 사료 대비 $0.05 \%$ 인 $0.2 \mathrm{~g}$ 을 사용하였다. 반추위액은 반추위 누 관이 장착된 Holstein 경산우에서 반추위 내용 물을 채취하여 보온병에 담아 $\mathrm{CO}_{2}$ gas를 충진 후 실험실로 운반하였으며, 내용물은 4겹의 cheese cloth로 2번 여과하였고, 이를 buffer 용 액 (McDougall, 1948)과 1:1로 혼합하여 반추위 배양액으로 사용하였다. 반추위 배양액의 희석 및 여과 전 과정을 nitrogen free $\mathrm{CO}_{2}$ 를 분사하 여 위액이 $\mathrm{O}_{2}$ 에 노출되지 않도록 유지하였으 며, $\mathrm{CO}_{2}$ bubbling으로 $\mathrm{pH}$ 7.0으로 보정하였다. 배양 전 반추위 배양액을 $40^{\circ} \mathrm{C}$ 로 유지할 수 있 도록 배양기내에서 보관하였다.

반추위 내 발효성상을 조사하기 위하여 사용 된 공시 사료는 $2 \mathrm{~mm}$ Wiley mill로 분쇄하여 pore size $250 \mu \mathrm{m}$ sieve를 통과시켜 미세입자를 제거하였고, 배양은 Tilly와 Terry (1963)의 방법 에 따라 실시하였으며, 각각 $4 \mathrm{~g}$ 의 시료가 함유 되어 있는 $250 \mathrm{ml}$ 의 flask에 $200 \mathrm{ml}$ 의 반추위 배 양액(100 ml 반추위액 $+100 \mathrm{ml}$ 버퍼)을 주입하 고, nitrogen free $\mathrm{CO}_{2}$ gas를 주입하면서 gas 조 절기가 장착된 butyl-rubber stoppers를 이용하여 배양용기를 혐기적으로 밀봉하였으며, 이를 39 $\pm 0.5^{\circ} \mathrm{C}$ 로 설정된 항온 교반기 (Vision Co, Ltd, Korea)에서 $150 \mathrm{rpm}$ 으로 교반 배양하였다. 배양 시간은 $3,6,12,24,48$ 시간으로 하였다. 배양 후 $\mathrm{pH}$ 측정은 먼저 각 처리구별 sample을 시간 별로 꺼내어 즉시 digital $\mathrm{pH}$ meter(ORION $290 \mathrm{~A}$, Korea)로 $\mathrm{pH}$ 를 측정하였으며, 건물소화 율은 Moore (1970)의 방법에 의하여, 공시 사료 의 분석은 AOAC (1990)의 방법에 준하여 사료 의 조성분을 분석하였고, Goering과 Van Soest (1970)의 분석 방법에 따라 $\mathrm{NDF}$ 와 $\mathrm{ADF}$ 를 분석 하였다. 반추위액의 $\mathrm{pH}$ 측정은 $\mathrm{pH}$ meter $(\mathrm{HM}$ $30 \mathrm{G}, \mathrm{Japan})$ 를 사용하여 측정하였다. 


\section{2. 유량 및 유성분 조사를 위한 동물 실험}

본 시험은 착유우의 보호아미노산의 추가공 급에 따른 유량 및 유성분 변화를 알아보기 위 하여 비유중기의 평균체중 $653 \pm 43 \mathrm{~kg}$ 으로 일 일 산유량이 $35 \pm 7.0 \mathrm{~kg}$, 유지방 $3.92 \pm 0.58 \%$, 유단백 $3.07 \pm 0.46 \%$, 산유일수 $145.29 \pm 18$ 일, 평균 3.9 산차인 Holstein 착유우 14 두를 산차 및 산유량 등을 고려하여 시험사료에 따른 2개군 (처리당 7두)으로 나눈 후 군사시켜 사양시험을 실시하였다. 공시동물은 2주간 기초사료를 급 여하여 사료적응기를 두었으며, 그 후 전 기간 동안 시험농장의 관행에 의하여 Table 1 에 나 타낸 농후사료와 조사료를 4:6비율로 일일 2회 (05:00와 17:00)에 걸쳐 동일한 양 $(25 \mathrm{~kg} /$ 두 $/$ 일, 건물기준)으로 나누어 급여하였다. 보호아미노 산은 보호라이신과 보호메치오닌을 3:1 비율로 섞은 $100 \mathrm{~g}$ 을 1 일 2 회로 나누어 오전과 오후 착 유시 정량 급여하였다. 급여사료의 화학적 조 성은 Table 1에 나타내었다.

우유시료는 주 2회 착유시 채취하였고, 산유 량은 Milkmeter(Waikato mark 5)로 6주간 측정 하여 평균을 구하고, 우유내 지방과 단백질 그 리고 MUN(milk urea nitrogen) 등의 유성분 분
석은 Milkoscan(Fossmatic 5000)으로 분석하였다. 유성분 함량은 오전에 채취한 우유시료의 유량 및 유성분을 기준으로 계산하였으며 $4 \%$ 유지 율 보정산유량 FCM은 Gaines와 Davidson(1923) 의 방법에 의한 공식으로 측정하였다.

유성분 함량(\%) =

$$
\begin{gathered}
\text { 오전유량 }(\mathrm{kg}) \times \text { 오전유성분 }(\%)+ \\
\text { 오전유량 }(\mathrm{kg}) \times \text { 오전유성분 } \\
\text { 일일유량 }(\mathrm{kg})
\end{gathered}
$$

4\% $\mathrm{FCM}=($ 유량, $\mathrm{kg} \times 0.4)+($ 유지량, $\mathrm{kg} \times 15)$ 유지량 $(\mathrm{kg})=$ 유량 $\times$ 유지율 $\div 100$

\section{3. 통계분석}

In vitro 및 in vivo 실험의 결과로 얻어진 대 조구와 보호아미노산 첨가구의 $\mathrm{pH}$, 건물소화율, 유량, 유성분 변화에 대한 통계처리는 SAS (Statistical Analysis System, 1996) package의 GLM (General Linear Model)을 이용하여 분산분 석 (ANOVA)을 실시하였으며 유의한 차이가 있 는 항목에 대해서는 T-test를 이용하여 유의성 차이를 검증하였다.

Table 1. Ingredient and Chemical composition of experimental diets for lactating cows (in vitro and in vivo \%, DM basis)

\begin{tabular}{lcccccc}
\hline \multirow{2}{*}{ Composition(\%) } & \multicolumn{7}{c}{ Ingredients } \\
\cline { 2 - 7 } & $\begin{array}{c}\text { Concentrate } \\
\text { mix }^{1)}\end{array}$ & $\begin{array}{c}\text { Beet } \\
\text { pulp }\end{array}$ & $\begin{array}{c}\text { Cotten } \\
\text { seed }\end{array}$ & Oat & $\begin{array}{c}\text { Alfalfa } \\
\text { hay }\end{array}$ & $\begin{array}{c}\text { Mineral } \\
\text { mix }^{2)}\end{array}$ \\
\hline \hline Dry matter & 89.50 & 89.29 & 90.36 & 94.79 & 82.86 & \\
Crude protein & 21.33 & 10.66 & 20.27 & 9.45 & 16.14 & \\
Crude fat & 5.62 & 0.94 & 21.94 & 3.57 & 2.41 & Free \\
Crude fiber & 10.34 & 25.80 & 34.06 & 35.43 & 41.11 & choice \\
Crude ash & 6.07 & 6.09 & 6.02 & 5.73 & 5.85 & \\
NDF & 50.07 & 56.42 & 55.42 & 72.01 & 54.30 & \\
ADF & 13.85 & 29.90 & 45.79 & 44.07 & 46.08 & \\
NFE & 46.14 & 45.81 & 8.07 & 40.61 & 27.34 & \\
Contents (\%) & 42.19 & 7.07 & 5.72 & 31.50 & 13.53 & \\
\hline
\end{tabular}

1) Commercial concentrate which was manufactured for lactating cows producing 25 35kg milk for day.

2) Containing $200 \mathrm{mg}$ manganese, $100 \mathrm{mg}$ cobalt, 4,000 mg sulfur, $150 \mathrm{mg}$ iodine, 2,000 iron, $100 \mathrm{mg}$ zinc, 100 mg copper, $50 \mathrm{mg}$ nickel, 2,000 mg calcium, 3,000 mg magnesium, $40 \mu g$ selenium. 


\section{III. 결과 및 고찰}

\section{1. 보호아미노산의 공급이 반추위 발효성상 에 미치는 영향 in vitro}

보호아미노산 추가공급에 따른 각 배양시간 별 반추위 내 $\mathrm{pH}$ 변화는 Table 2에서 보는 바 와 같다. 실험은 전체적으로 실험 개시부터 종 료까지 배양시간이 경과함에 따라 대조구와 첨 가구 모두 비슷하게 감소하는 경향을 나타내었 다. 실험개시 $\mathrm{pH}$ 는 대조구, 처리구 각각 6.95 및 6.92이었으며, 배양시간 경과에 따른 $\mathrm{pH}$ 변 화는 0 시간에서 3 시간 사이에 크게 나타났으 나, 배양종료시간인 48시간에 대조구와 처리구 각각 5.40 및 5.39로 비슷하였으며 통계적 유의 차는 없었다.

발효시간에 따른 반추위 내 건물소화율의 변 화는 Table 2에 나타내었다. 배양개시 소화율은 대조구와 처리구 각각 26.59 및 28.17\%였으며, 배양시간이 경과함에 따라 전체적으로 증가하 는 경향을 보였다. 배양 종료시간인 48시간에 대조구는 $57.83 \%$, 처리구는 $60.25 \%$ 의 소화율을 나타내었다. 전체 발효시간동안 처리구의 건물 소화율이 높게 나타나는 경향이 있었으나 통계 적 유의차는 찾아 볼 수 없었다. 위와 같이 $\mathrm{pH}$ 변화와 건물소화율의 결과로 볼 때 반추위 내 에서 보호아미노산 추가 급여가 반추위미생물 의 건물분해능력 및 활성도 등에 특별한 영향
을 주지 않는 것으로 나타났는데, 일반적으로 보호아미노산 급여 시 반추위 내 $\mathrm{pH}$ 에는 큰 변화가 없다는 보고와 일치하였다 (Wright와 Loerch, 1988).

\section{2. 보호아미노산의 공급이 비유중기 착유우} 의 유량 및 유성분에 미치는 영향 in vivo

본 실험은 보호아미노산 추가공급에 따른 비 유중기 착유우의 유량 및 유성분의 변화를 조 사하였다. 실험 결과는 개체별 산유량 및 유성 분을 대조구와 비교하기 용이하게 하기 위하여 실험 개시 전과 후의 성적의 차이를 100 으로 보정하여 제시하였다.

실험기간 동안 평균산유량은 대조구는 두당 $20.2 \mathrm{~kg}$ 인데 비하여 처리구는 $28.75 \mathrm{~kg}$ 으로 높은 차이를 나타내었다 $(\mathrm{P}<0.001$, Table 3$)$. 이러한 차이는 공시축의 실험 전 산유량에 의한 차이 와 보호아미노산 추가공급에 기인하는 것으로 판단된다. Fig. 1은 보호아미노산 추가 공급 후 6 주간의 산유량의 변화를 나타내었는데, 대조 구와 처리구 모두 비유기간이 경과할수록 산유 량이 감소하는 것을 보여주고 있다. 그러나 산 유량의 감소는 대조구에 비하여 처리구에서 감 소폭이 낮은 경향을 보였다. 산유량을 실험 전 과 후의 차이를 100 으로 보정하여 보면, 대조 구에서는 $11.92 \%$ 가 감소한 반면 처리구에서는 $5.68 \%$ 만 감소하였으나 통계적 유의성은 나타나

Table 2. Effects of supplementation of ruminally protected amino acid on ruminal $\mathrm{pH}$ and dry matter digestibility, in vitro

\begin{tabular}{rccccc}
\hline \multirow{2}{*}{ Time } & \multicolumn{3}{c}{$\mathrm{pH}$} & & \multicolumn{2}{c}{ Dry matter digestibility(\%) } \\
\cline { 2 - 3 } \cline { 5 - 6 } & Control $^{1)}$ & Treatment $^{2}$ & & Control & Treatment \\
\hline \hline $3 \mathrm{~h}$ & 6.54 & 6.40 & & 26.59 & 28.17 \\
$6 \mathrm{~h}$ & 6.10 & 6.08 & & 30.71 & 33.03 \\
$12 \mathrm{~h}$ & 5.72 & 5.71 & & 36.39 & 36.18 \\
$24 \mathrm{~h}$ & 5.45 & 5.44 & & 43.92 & 45.39 \\
$48 \mathrm{~h}$ & 5.40 & 5.39 & & 55.00 & 56.15 \\
\hline
\end{tabular}

1) Without supplementation of ruminally protected amino acid.

2) $0.2 \mathrm{~g}$ of ruminally protected amino acids (2.71\% of PRLys and $0.90 \%$ of PRMet) was incubated with $200 \mathrm{ml}$ rumen inoculum at $39 \pm 0.5^{\circ} \mathrm{C}$ incubator for $48 \mathrm{~h}$.

Means with different superscript in the same column are significantly different $(\mathrm{P}<0.05)$. 
Table 3. Effects of supplementation of ruminally protected amino acids on DM intake, milk yield and milk compositions in mid-lactating cows

\begin{tabular}{|c|c|c|c|}
\hline \multirow{2}{*}{ Items } & \multicolumn{3}{|c|}{ Milk yield and milk compositions ${ }^{1)}$} \\
\hline & Control $^{5)}$ & Treatment ${ }^{6)}$ & P value ${ }^{2)}$ \\
\hline DM intake, kg & $23.78 \pm 1.17$ & $23.81 \pm 0.89$ & NS \\
\hline Milk yield, kg & $20.20 \pm 0.27$ & $28.75 \pm 0.68$ & $<0.001$ \\
\hline $4 \% \mathrm{FCM}^{3)}, \mathrm{kg}$ & $20.02 \pm 0.49$ & $28.04 \pm 0.87$ & $<0.001$ \\
\hline Fat, \% & $3.94 \pm 0.07$ & $3.93 \pm 0.07$ & NS \\
\hline Fat, kg & $0.79 \pm 0.03$ & $1.10 \pm 0.04$ & $<0.001$ \\
\hline Protein, \% & $3.23 \pm 0.02$ & $3.24 \pm 0.07$ & NS \\
\hline Protein, kg & $0.66 \pm 0.01$ & $0.90 \pm 0.03$ & $<0.001$ \\
\hline \multirow[t]{2}{*}{$\mathrm{MUN}^{4)}, \mathrm{mg} / \mathrm{dl}$} & $15.36 \pm 1.18$ & $15.52 \pm 1.01$ & NS \\
\hline & \multicolumn{3}{|c|}{ Index against $0 \%^{7,8)}$} \\
\hline Milk yield, \% & $-11.92 \pm 2.84$ & $-5.68 \pm 1.84$ & 0.090 \\
\hline 4\% FCM, \% & $-11.25 \pm 2.60$ & $-6.16 \pm 1.87$ & 0.138 \\
\hline Fat, \% & $+0.40 \pm 0.48$ & $+0.06 \pm 0.56$ & 0.646 \\
\hline Fat, \% & $-9.17 \pm 2.67$ & $-3.03 \pm 1.89$ & 0.085 \\
\hline Protein, \% & $+0.80 \pm 0.57$ & $+2.62 \pm 1.12$ & 0.172 \\
\hline Protein, \% & $-11.09 \pm 2.45$ & $-5.47 \pm 1.82$ & 0.090 \\
\hline MUN, \% & $+31.00 \pm 9.62$ & $+4.70 \pm 4.98$ & 0.032 \\
\hline $\begin{array}{l}\text { 1) Values are means } \\
\text { 2) NS: Not significan } \\
\text { 3) FCM: Fat correcte } \\
\text { 4) MUN: Milk urea } \\
\text { 5) Without supplemer } \\
\text { 6) Supplementation o } \\
\text { 7) - : decrease rate } \\
\text { 8) } \\
\text { + : increase rates. }\end{array}$ & $\begin{array}{l}\text { ally protected am } \\
\text { ected amino acid }\end{array}$ & PRLys and 0.90 & 100g per day). \\
\hline
\end{tabular}

지 않았다. 그러나 전반적인 경향으로 보아 보 호아미노산의 추가 공급이 비유중기 착유우의 산유량에 긍정적인 영향을 미치는 것으로 판단 되었다.

비유중기 착유우의 $4 \% \mathrm{FCM}$ 평균생산량을 보면, 실험기간동안 대조구와 처리구의 평균 4\% FCM 생산량은 대조구와 처리구 각각 20.02 와 $28.04 \mathrm{~kg}$ 으로 처리구에서 높게 나타나 시험 구간 차이를 나타내었다 $(\mathrm{P}<0.001)$. 실험 전과 후의 차이를 100 으로 보정한 결과를 보면, 두 시험구 모두 감소하는 경향을 나타내었는데 대 조구에서 $11.25 \%$ 감소한 반면 처리구에서는 $6.16 \%$ 감소에 그쳐 보호아미노산 첨가가 $4 \%$ $\mathrm{FCM}$ 생산에 긍정적인 영향을 가져다주는 것으 로 보여진다. Fig. 2는 실험 전과 후의 차이를 100 으로 보정 후 6 주간 두 시험구의 $4 \% \mathrm{FCM}$
감소 추이를 나타내었다. 대조구에서 실험 개 시 1 주가 지난 후 $3.33 \%$ 가 감소하였으며, 2주 후에는 $12.87 \%$ 가 감소하였다. 이러한 감소 추 세는 실험 종료기간 인 실험 후 6주 $(18.67 \%)$ 까 지 지속되는 경향을 보여 주었으며 또한 처리 구에서도 보호아미노산 첨가에도 불구하고 $4 \%$ $\mathrm{FCM}$ 이 감소하는 경향을 보여 주었다. 그러나 처리구에서의 $4 \% \mathrm{FCM}$ 의 감소 비율은 대조구 보다 다소 완만한 경향을 나타내었다. 처리구 의 $4 \% \mathrm{FCM}$ 감소 비율을 보면, 실험 개시 1 주 후 $0.05 \%$ 를 나타내어 약간 증가하였다가 3주차 에는 $8.44 \%$ 그리고 6 주차에는 $10.65 \%$ 의 감소율 을 나타내었다. 대조구에 비하여 처리구에서 $4 \% \mathrm{FCM}$ 및 유량의 감소율이 낮게 나타난 것 은 보호아미노산의 급여효과에 기인한 것으로 보인다(Schwab 등, 1989; Chapoutot 등, 1992; 


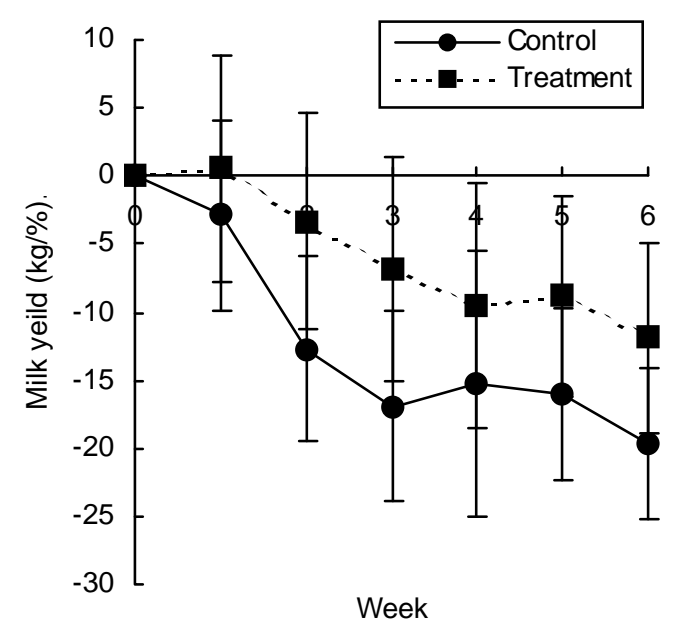

Fig. 1. Changes (\%) in milk yield (kg) in midlactating cows fed control diet and experimental diet containing protected amino acids (Index against 0\%). Control: Without supplementation of ruminally protected amino acid. Treatment: Supplementation of ruminally protected amino acid (2.71\% of PRLys and $0.90 \%$ of PRMet $100 \mathrm{~g}$ per day).

Robinson 등, 1992).

보호아미노산을 첨가한 사료가 비유중기 젖 소의 유지방율(\%)과 100 으로 보정 후 실험 기 간동안의 변화 추이 등에 미치는 영향을 Table 3 및 Fig. 3, 4에 나타내었다. 본 실험을 통하여 얻은 대조구와 처리구의 유지방율(\%)은 각각 3.94 와 $3.93 \%$ 로 두 시험구간 유의성을 나타내 지 못하였다. 그러나 유지방 생성량으로 다시 계산한 결과 대조구와 처리구에서 각각 평균 $0.79 \mathrm{~kg}$ 과 $1.10 \mathrm{~kg}$ 으로 나타나 처리구간 유의성 이 나타났다 $(\mathrm{P}<0.001)$, 각 처리구의 유지방율 (\%) 및 생성량 $(\mathrm{kg})$ 을 100 으로 보정하였을 경우 에는 유지방 함량이 대조구에서 $0.40 \%$ 증가하 였고, 처리구에서는 $0.06 \%$ 증가하는 것으로 조 사되었다. 반면, 유지방 생성량 $(\mathrm{kg})$ 은 대조구는 $9.17 \%$ 가 감소한 결과를 보였고 처리구는 $3.03 \%$ 만이 감소하는 결과를 나타내었다 ( $\mathrm{P}>0.085)$.

Fig. 3은 대조구와 처리구의 유지방율(\%)을 100 으로 보정 후 시험기간 동안의 변화하는 양 상을 그래프로 나타내었는데, 시험 시작 3주

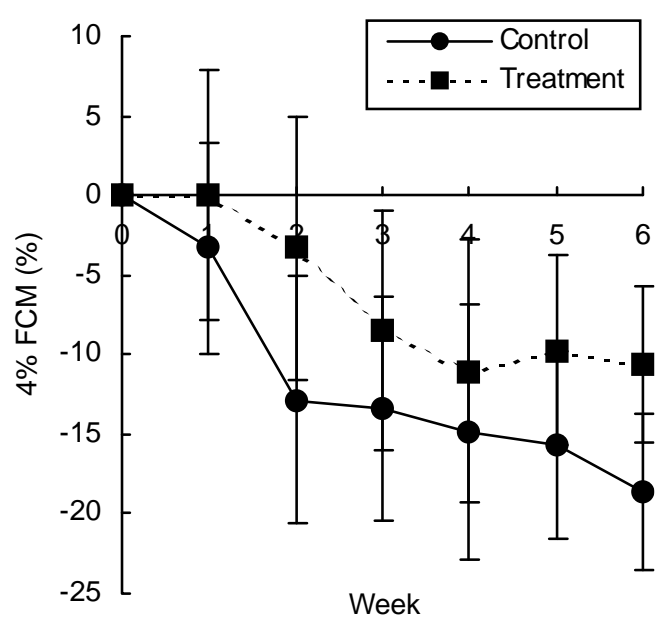

Fig. 2. Changes (\%) in $4 \%$ FCM yield (kg) in mid-lactating cows fed control diet and experimental diet containing protected amino acids (Index against 0\%). FCM : Fat corrected milk. Control: Without supplementation of ruminally protected amino acid. Treatment: Supplementation of ruminally protected amino acid $(2.71 \%$ of PRLys and $0.90 \%$ of PRMet $100 \mathrm{~g}$ per day).

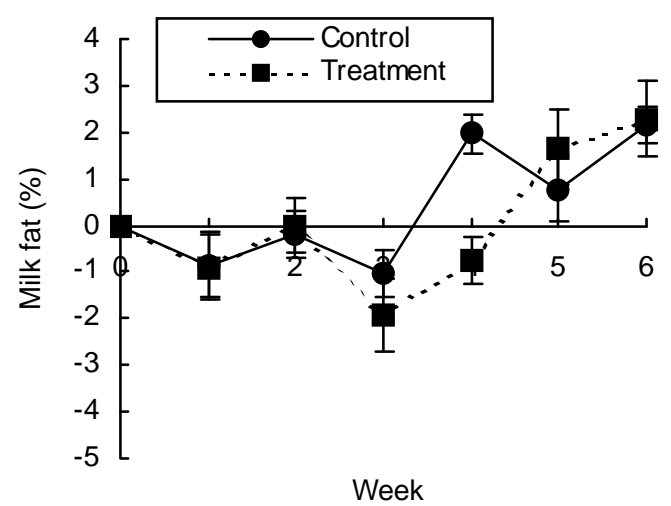

Fig. 3. Changes (\%) in milk fat percent (\%) in mid-lactating cows fed control diet and experimental diet containing protected amino acids (Index against 0\%). Control: Without supplementation of ruminally protected amino acid. Treatment : Supplementation of ruminally protected amino acid (2.71\% of PRLys and $0.90 \%$ of PRMet $100 \mathrm{~g}$ per day). 


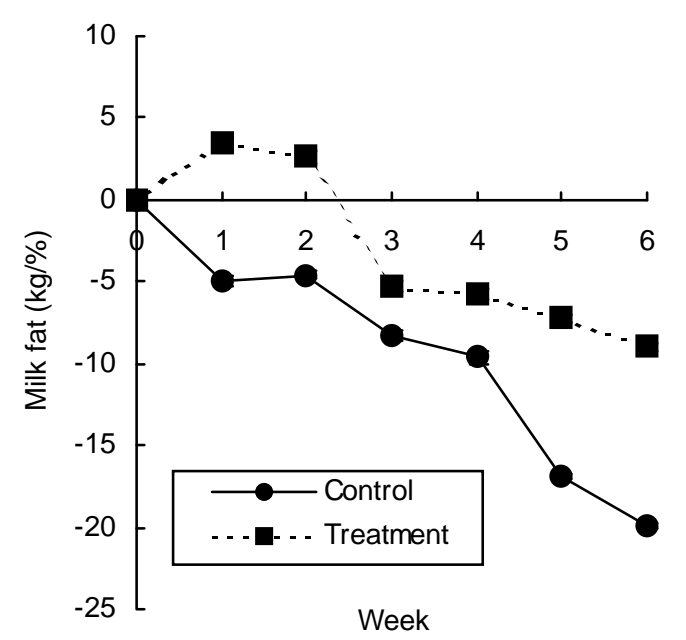

Fig. 4. Changes (\%) in milk fat yield $(\mathrm{kg})$ in mid-lactating cows fed control diet and experimental diet containing protected amino acids (Index against 0\%). Control: Without supplementation of ruminally protected amino acid. Treatment: Supplementation of ruminally protected amino acid $(2.71$ $\%$ of PRLys and $0.90 \%$ of PRMet $100 \mathrm{~g}$ per day).

동안은 두 처리구 모두 감소하는 경향을 보이다 가 시험 시작 4주 후부터는 대조구와 처리구 모두 유지방율이 증가하는 경향을 나타내었다. 그러나 유지방 생성량 $(\mathrm{kg})$ 을 100으로 보정하였 을 경우, 대조구에서 유지방 생성량이 급격히 감소하는 것으로 나타났다. 마찬가지로 처리구 에서도 유지방 생성량이 감소하는 것으로 나타 났으나 대조구에 비하여 감소폭은 낮아지는 것 으로 조사되었다(Fig. 4). 따라서 비유 중기 착 유우에 보호아미노산을 추가 급여할 경우 급격 히 감소하는 유지방 생성량 $(\mathrm{kg})$ 을 어느정도 완 화시켜 주는 것으로 조사되었다. 보호아미노산 을 첨가 급여한 Robinson 등(1992)도 비유초기 의 젖소에서 PRLys과 PRMet 급여가 산유량과 유성분에 미치는 영향을 연구하였는데, PRLys 과 PRMet 급여는 산유량과 유단백질 함량 및 생산량을 증가시켰고, 유지방도 높였다고 보고 하였으며, Canale 등(1990)도 고능력우 사료에 지방과 반추위 보호아미노산을 급여한 시험에
서 지방과 보호아미노산을 동시에 공급하여 유 지율과 유지방 함량이 증가하였다고 보고하여, 본 실험에서도 유지방율(\%) 및 유지방 생성량 $(\mathrm{kg})$ 이 증가하는 결과를 보인 것이라 사료된다.

대조구와 처리구의 평균 유단백질 함량(\%), 유단백질 생성량 $(\mathrm{kg})$ 과 이를 100 으로 보정하여 증감 비율을 비교하였다. 대조구와 처리구의 평균 유단백 함량은 각각 $3.23 \%$ 와 $3.24 \%$ 을 나 타내어 시험구간 유의성은 없었다 (Table 3). 그 러나 유단백질 생성량은 대조구에서 $0.66 \mathrm{~kg}$ 그 리고 처리구에서 $0.90 \mathrm{~kg}$ 으로 보호아미노산 급 여로 인한 유의성이 인정되었다 $(\mathrm{P}<0.001)$. 유단 백질 함량을 100 으로 보정하여 조사한 결과, 대조구에서는 $0.80 \%$ 가 증가하였고 대조구에서 는 $2.62 \%$ 가 증가하여 보호아미노산 추가급여로 인하여 비유중기 착유우의 유단백질 함량이 증 가하였으나 유의적인 차이는 발견하지 못하였 다 $(\mathrm{P}>0.172)$, 마찬가지로, 유단백질 생성량의 감소 경향도 대조구에 비하여 처리구에서 유의 성 없이 천천히 감소하는 것으로 조사되었다. Fig. 5와 6은 실험 시작 후 6주간 유단백질 함 량 및 유지방 생성량 값을 100으로 보정 후 변 화하는 경향을 나타내었다. 유단백질 함량은 실험시작 4주 후부터 처리구에서 대조구에 비 하여 증가하는 경향을 보였으며 (Fig. 5), 유단 백 생성량 $(\mathrm{kg})$ 은 실험 기간 동안 대조구는 $18.60 \%$ 가 감소하였고, 처리구는 $9.87 \%$ 가 감소 하여 처리구가 대조구보다 낮은 감소 비율을 나타내어 ( $<<0.05$, Fig. 6) Schwab 등 (1976), Donkin 등 (1989)과 Sloan 등 (1989)의 보고와 일 치하였다. 보호아미노산의 급여로 인한 유단백 질 함량이 증가하는 것은 다른 성분에 비하여 보다 분명한 경향이 있는 것으로 보였으나 통 계적 유의차는 나타나지 않았는데 본 실험에서 사용한 공시동물은 비유중기 착유우를 이용하 였기 때문인 것으로 판단된다.

보호아미노산 추가 공급으로 인한 우유내 요 소태질소 (Milk Urea Nitrogen; MUN) 함량 및 그 변화를 Table 3과 Fig. 7에 나타내었다. 대조 구의 평균 MUN 함량은 $15.36 \mathrm{mg} / \mathrm{dl}$ 로 처리구의 $15.52 \mathrm{mg} / \mathrm{dl}$ 와 유사하게 나타났다. 그러나 이를 100 으로 보정 하였을 경우 대조구는 $31.0 \%$ 의 


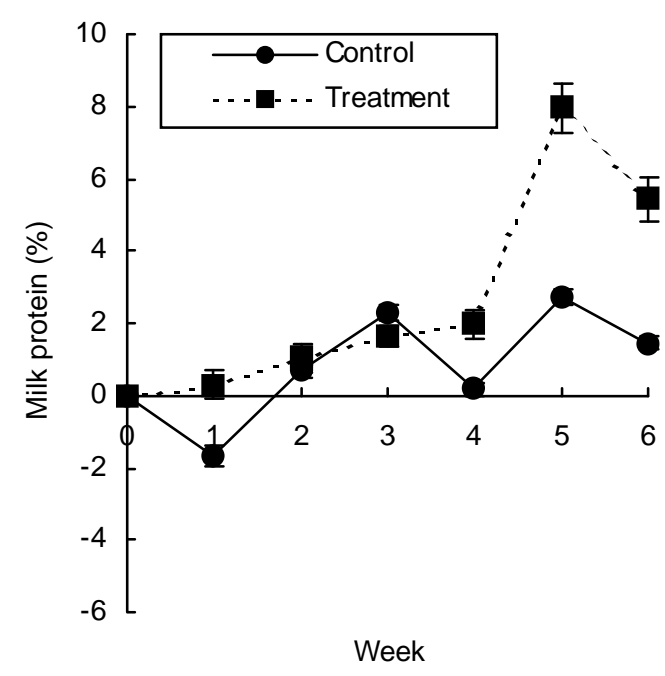

Fig. 5. Changes (\%) in milk protein percent (\%) in mid-lactating cows fed control diet and experimental diet containing protected amino acids (Index against 0\%). Control: Without supplementation of ruminally protected amino acid. Treatment: Supplementation of ruminally protected amino acid (2.71 $\%$ of PRLys and $0.90 \%$ of PRMet $100 \mathrm{~g}$ per day).

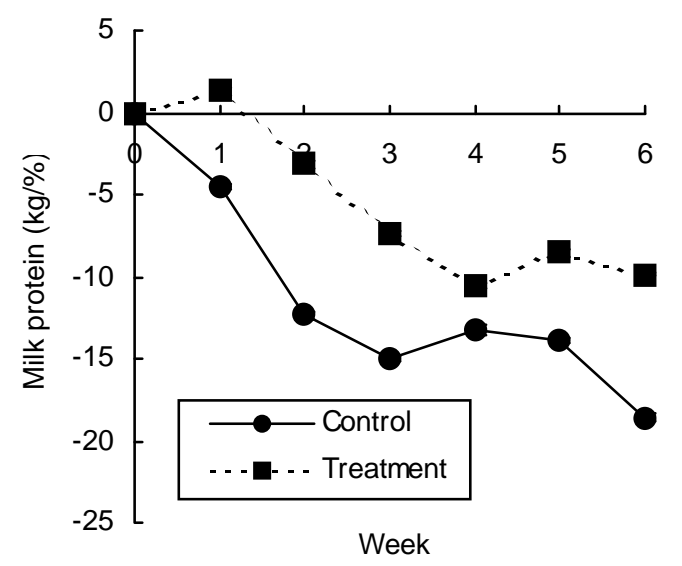

Fig. 6. Changes (\%) in milk protein yield $(\mathrm{kg})$ in mid-lactating cows fed control diet and experimental diet containing protected amino acids (Index against 0\%). Control: Without supplementation of ruminally protected amino acid. Treatment: Supplementation of ruminally protected amino acid (2.71 $\%$ of PRLys and $0.90 \%$ of PRMet $100 \mathrm{~g}$ per day).

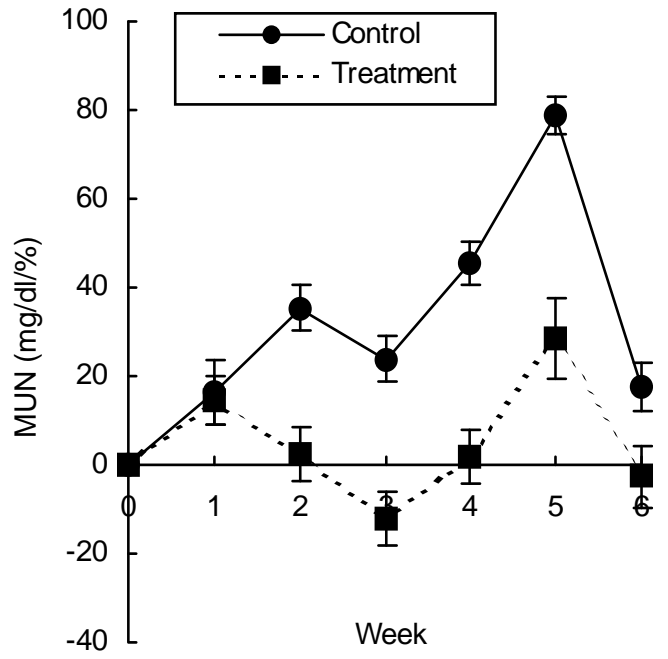

Fig. 7. Changes (\%) in MUN yield (mg/dl) in mid-lactating cows fed control diet and experimental diet containing protected amino acids (Index against 0\%). MUN: Milk urea nitrogen. Control: Without supplementation of ruminally protected amino acid. Treatment: Supplementation of ruminally protected amino acid $(2.71 \%$ of PRLys and $0.90 \%$ of PRMet $100 \mathrm{~g}$ per day).

증가를 보인 반면, 처리구는 $4.70 \%$ 의 $\mathrm{MUN}$ 함 량 증가를 나타내었다 $(\mathrm{P}<0.05)$. 실험기간동안 우유내 MUN 농도 변화를 보면, 실험 1주 째에 는 대조구, 처리구 모두 비슷한 농도를 나타내 었으나 실험 1주 후부터는 대조구에서 처리구 보다 MUN 농도가 높게 형성되었으며 이러한 경향은 실험 종료시기인 실험 시작 후 6주까지 지속적으로 나타났다(Fig. 7). 우유 중 요소태 질소 (Milk Urea Nitrogen; MUN)는 사료 중 단 백질을 과다하게 급여하거나 에너지 부족시에 MUN 수치는 높아지고, 단백질이 부족하거나 에너지가 증가하였을 때 MUN 수치는 낮아진 다 (Oltner와 Wiktorsson, 1983; Roseler 등, 1993; Hof 등, 1997). 본 실험에서의 결과는 문 등 (2000)의 문헌에 소개된 미국의 기준 $(12 \mathrm{mg} / \mathrm{dl}$ $\sim 18 \mathrm{mg} / \mathrm{dl}$ ) 범위에 속하므로 보호아미노산 첨가 가 적절하게 사용되었다고 사료된다. 아울러, 본 연구결과를 보면, 반추동물에 보호아미노산 의 추가 급여가 우유내 요소태질소 함량을 적 
정수준으로 안정화시키는 기능을 하는 것으로 보여지나 아직까지 이에 대한 연구보고는 찾아 볼 수 없어 추가적인 연구가 필요하다고 사료 된다. 이상의 결과에서 볼 때 비유중기 착유우 에서 보호 lysine과 보호 methionine의 급여는 유량의 감소 및 각 성분량의 감소를 방지하는 것으로 나타나 고능력우의 비유중기 시기에 급 여효과가 충분한 것으로 나타났다.

$$
\text { IV. 요 약 }
$$

본 연구는 보호아미노산 추가 공급이 비유중 기 착유우의 반추위 발효 성상 및 유생산량과 유성분 등의 생산성 변화를 알아보기 위하여 in vitro 시험과 in vivo 시험을 각각 실시하였 다. In vitro 시험은 각각 $4 \mathrm{~g}$ 의 공시사료를 이용 하였으며, 처리구에는 보호라이신 (PRLys, 2.71 \%)과 보호메치오닌 (PRMet, 0.90\%)을 3:1로 혼 합하여 첨가한 후 48시간동안 배양한 후 처리 구와 대조구의 $\mathrm{pH}$ 와 건물소화율을 확인하였다. 또한 In vivo 시험은 3:1로 혼합한 보호라이신 (PRLys, 2.71\%)과 보호메치오닌 (PRMet, 0.90\%) $100 \mathrm{~g}$ 을 1일 2회로 나누어 비유 중기 착유우에 오전과 오후 착유 시 정량급여 한 후 생산되는 우유의 양 그리고 유성분의 변화를 조사하였 다. 아미노산의 추가 급여로 인한 in vitro 반추 위 $\mathrm{pH}$ 와 건물소화율은 배양시간이 경과함에 따라 감소하는 경향을 나타냈으나 대조구에 비 하여 유의성은 나타나지 않았다. 따라서 본 연 구에서 사용된 보호아미노산은 반추위 미생물 의 건물분해 능력 등 반추위 발효성상에 악 영 향을 미치지 않은 것으로 판단된다. 비유중기 착유우에 보호아미노산 급여기간에 따른 유생 산량은 시간이 지남에 따라 대조구와 처리구에 서 모두 감소하는 경향을 보였으나, 이는 시험 기간이 경과함에 따른 착유일수 증가로 인한 자연감소로 보여지며, 대조구에서 보다 처리구 에서의 유량감소율이 적었다. 4\% FCM과 유단 백생성량은 대조구에서 각각 $11.25 \%, 11.09 \%$ 그리고 처리구에서 $6.16 \%, 5.47 \%$ 의 감소를 나 타내어 대조구보다 처리구에서 감소 비율이 낮 았다. 보호아미노산 첨가 시 우유중 지방생성
량은 대조구 $(0.79 \mathrm{~kg})$ 에 비하여 처리구 $(1.10 \mathrm{~kg})$ 에서 유의한 차이를 나타내었다 $(\mathrm{P}<0.05)$. 이상 의 결과를 종합해 볼 때 in vitro의 경우 보호아 미노산 첨가시 반추위 내 발효성상에 문제가 없었고, 비유중기 착유우를 대상으로 한 in vivo 시험에서는 처리구에서 산유량 및 유성분의 감 소가 대조구보다 적었으며 이는 고능력우의 비 유중기 시기에 보호아미노산을 급여할 경우 산 유량 및 유성분의 감소비율을 효과적으로 개선 시킬 수 있는 것으로 판단된다.

\section{V. 인 용 문 헌}

1. A. O. A. C. 1990. Official Methods of Analysis (15th ed.) Association of Official Agricutural Chemists Washington, D. C. 13th ed.

2. ARC. 1980. The Nutrient Requirements of Ruminant Livestock. Commonwealth Agricultural Bureaux, Slough, England.

3. Canale, C. J., Muller, L. D., McCahon, H. A., Whitsel, T. J., Varge, G. A. and Lormore, M. J. 1990. Dietary fat and ruminally protected amino acids for high producing dairy cows. J. Dairy Sci. 73:135.

4. Chalupa, W. 1974. Rumen bypass and protection of proteins and ruminants. U. S. Patent 3,619,200.

5. Chapoutot, P., Schmidely, P. and Sauvant, D. 1992. Influence of a ruminally protected blend of methionine and lysine on the dairy cow nutrion and production. J. Dairy Sci.(suppl. 1):199(abstr.).

6. Donkin, S. S., Varga, G. A., Sweeney, T. F. and Muller, L. D. 1989. Rumen-protected methionine and lysine : Effects on animal performance, milk protein yield and physiological measures. J. Dairy Sci. 72:1484.

7. Folman, Y., Neumark, H., Kaim, M. and Kaufmann, W. 1981. Rerformance, rumen and blood metabolites in high-yielding cows fed varying protein percent, and protected soybean. J. Dairy Sci. 64:59.

8. Gaines, W. L. and Davidson, F. A. 1923. Relation between percentage fat content and yield of milk. 
Correction of milk yeild for fat content. Illinois Agr. Expt. Sta. Bull. No. 245.

9. Goering, H. K. and Van Soest, P. J. 1970. Forage fiber analysis (apparatus, reagents, procedure and application). Agric. Handbook 379. ARS. Washington D. C.

10. Hof, G., Vervorn, M. D., Lenaers, P. J. and Tarnminga. S. 1997. Milk urea nitrogen as a tool to moniter the protein nutrition of dairy cows. J. Dairy Sci. 80:333.

11. Hogan, J. P. 1975. Quntitative aspects of nitrogen utilization in ruminants. J. Dairy Sci. 58:11641177.

12. Illg, D. J., Sommerfeldt, J. L. and Schingoche, D. J. 1987. Lactational and systemic responses to the supplementation of protected methionine in soybean meal diets. J. Dairy Sci. 70:620.

13. McDougall, E. J. 1948 . Studies of ruminant saliva. 1. The composition of output of sheep's saliva. Biochem. J. 43, 99-109.

14. Moore, J. E. 1970. Procedure for two-stage in vitro digestion of forage. In L. E. Harrison(ed.). Nutrition research technique for domestic and animals. J. Brit. Grassl. Sci. 18:119.

15. NRC. 2001. Nutrient Requirements of Dairy Cattle. Seventh Revised Edition.

16. Oldham, J. D. 1981. Amino acid requirements for lactation in high-yielding dairy cows. In: Recent Advances in Animal Nutrition. W. Haresign, ed. Butterworths, London, Engl. pp. 33.

17. Oltner, R. and Wiktorsson, H. 1983. Urea concentrations in milk and blood as influenced feeding varying amounts of protein and energy of dairy cows. Live. Prod Sci. 10:457.

18. Robinson, P. H., Chalapa, W., Julien, W., Sato, K., Suzuki, H. and McQueen, R. E. 1992. Supplemental rumen-protected amino acids for early lactation dairy cattle. J. Dairy. Sci. (suppl. 1):199(abstr).

19. Rogers, J. A., Peirce-Sander, S. B. and Papas, A.
M. 1989. Production responses of dairy cows fed various amounts of rumen-protected methionine and lysine. J. Dairy. Sci. 72:1800.

20. Roseler, D. K., Feruson. J. D. Sniffen, C. J. and Herrema. J. 1993. Dietary protein degradability effect on plasma and milk urea nitrogen and milk nonprotein nitrogen in Holstein cows. J. Dairy Sci. 76:525.

21. SAS User's Guide: Statistics, Version 6.12 Edition. 1996. SAS Inst.., Inc., Cary., NC.

22. Schwab, C. G., Bozak, C. K., Whitehouse, N. L. and Olsin, V. M. 1989. Extent of lysine limitation in mid lactation cows fed a corn-based ration. J. Dairy. Sci. 72(Suppl. 1):506(abstr.).

23. Schwab, C. G., Satter, L. D. and Clay, A. B. 1976. Response of lactating dairy cows to abomasal infusion of amino acids. J. Dairy Sci. 59:1254.

24. Sloan, B. K., Robert, J. C. and Mathe, J. 1989. Influence of dietary crude protein of cocconut plus or minus inclusion or rumen-protected amino acids(RAA) on the early lactation performance of heifers. J. Dairy Sci. 72(suppl. 1):506(abstr.).

25. Tilly, J. M. A. and Terry, R. A. 1963. A two stage technique for in vitro digestion of forage crop. J. Brit. Brit. Grass. Soc. 18:104-111.

26. Van Soest, P. V. 1982. Carbohydrate In : Nutritional ecology of the ruminants. pp. 106-108. $\mathrm{O}$ and Books, INC., Corrallis. OR. USA.

27. Wright, M. D. and Loerch, S. C. 1988. Effects of rumen-protected amino acids on ruminant nitrogen balance, plasma amino acid concentrations and performance. J. Anim. Sci. 66:2014

28. 문진산, 주이석, 장금찬, 윤용덕, 이보균, 박용호, 손창호. 2000. 우유 중 단백질과 요소태질소 분 석에 의한 젖소의 에너지 및 단백질 균형상태 평가에 관한 연구. 한국동물자원과학회지 42(4): 499.

(접수일자 : 2008. 1. 18. / 채택일자 : 2008. 4. 10.) 